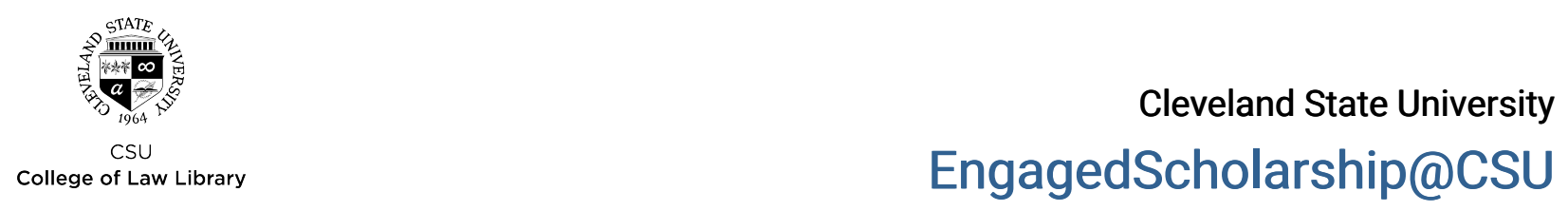

2016

\title{
President Obama's Legacy: The Iran Nuclear Agreement?
}

\author{
Milena Sterio \\ Cleveland-Marshall College of Law, Cleveland State University, m.sterio@csuohio.edu
}

Follow this and additional works at: https://engagedscholarship.csuohio.edu/fac_articles

Part of the International Law Commons, Military, War, and Peace Commons, and the National Security Law Commons

How does access to this work benefit you? Let us know!

\section{Repository Citation}

Sterio, Milena, "President Obama's Legacy: The Iran Nuclear Agreement?" (2016). Law Faculty Articles and Essays. 863.

https://engagedscholarship.csuohio.edu/fac_articles/863

This Article is brought to you for free and open access by the Faculty Scholarship at EngagedScholarship@CSU. It has been accepted for inclusion in Law Faculty Articles and Essays by an authorized administrator of EngagedScholarship@CSU. For more information, please contact research.services@law.csuohio.edu. 


\title{
President Obama's Legacy: The Iran NuClear AgreEMEnt?
}

\author{
Milena Sterio*
}

Iran, the United States, and several world super-powers signed a historic nuclear agreement over the summer of 2015. The Agreement is a comprehensive plan of action, with an unprecedented level of minutia and detail regarding Iran's commitment to curb its nuclear program in exchange for the lifting of United Nations-imposed sanctions against Iran. This Agreement, if it is successfully implemented, may represent President Obama's most significant foreign policy achievement and may become the most important element of President Obama's legacy. This Article will examine the Iran Nuclear Agreement by focusing on the events which led to the imposition of sanctions against Iran and to the ultimate negotiation of this Agreement, the structure of the Agreement; this Article will also discuss the most significant advantages and disadvantages of this somewhat risky deal. This Article will conclude that the Iran Nuclear Agreement could become one of President Obama's biggest foreign policy accomplishments in the Middle East.

\section{COnTEnts}

I. INTRODUCTION 69

II. Prelude: What Lead to the Agreement? .................................. 70

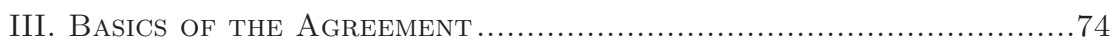

IV. (Dis)Advantages of the Agreement .................................... 77

V. Post-Agreement: Implementation and Obama's Legacy? .............79

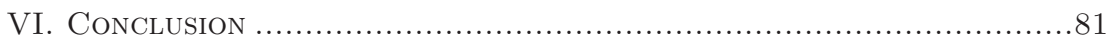

\section{INTRODUCTION}

Iran and several world super-powers, including the United States, signed a historic nuclear agreement over the summer of 2015. The Joint Comprehensive Plan of Action [hereinafter "Agreement"] was signed on July 14, 2015 in Vienna by the United States, Great

* The Charles R. Emrick Jr. - Calfee Halter \& Griswold Professor of Law and Associate Dean for Academic Enrichment, Cleveland-Marshall College of Law. The author would like to thank the Frederick K. Cox International Law Center at Case Western Reserve University School of Law, and in particular, the organizers of this conference, New

Beginnings, Resets and Pivots: The International Legal Practice of the Obama Administration - ILW/Midwest 2015, for the opportunity to present these remarks. 
Britain, France, Germany, China, Russia, the European Union High Representative for Foreign Affairs and Security Policy, and Iran. ${ }^{1}$ It is over one hundred pages long and has five annexes; some commentators have indicated that the level of minutia and detail in this agreement is unprecedented in terms of other nuclear nonproliferation agreements throughout history. ${ }^{2}$ Under the terms of the Agreement, Iran agreed to curb its nuclear program in exchange for the lifting of United Nations-imposed sanctions against Iran. ${ }^{3}$ The Agreement, if successfully implemented, may represent one of President Obama's most significant foreign policy achievements and may become a cornerstone of Obama's legacy. This Article will examine the Iran Nuclear Agreement by focusing on the events which led to the imposition of sanctions against Iran and to the ultimate negotiation of this Agreement (II), the structure of the Agreement (III), and will discuss the most significant advantages and disadvantages of this somewhat risky deal (IV). This Article will conclude that the Iran Nuclear Agreement could become one of President Obama's biggest accomplishments regarding foreign policy $(\mathrm{V})$.

\section{Prelude: What Lead to the Agreement?}

Iran signed the Non-Proliferation of Nuclear Weapons Treaty (NPT) in 1968 as a non-nuclear weapons state and ratified the NPT in $1970 .{ }^{4}$ However, in the 1970s even as a member of the NPT, Iran began developing nuclear technology when the United States' Atoms for Peace program began providing assistance to Iran, led by the American-supported Shah. ${ }^{5}$

1. Joint Comprehensive Plan of Action, U.S. Dep't of State (July 14, 2015), http://www.state.gov/documents/organization/245317.pdf [http://perma.cc/9DBJ-XEX4].

2. See John Mecklin, The Experts Assess the Iran Agreement of 2015, BULLETIN ATOMIC SCIENTISTS (July 14, 2015, 2:31 AM), available at http://thebulletin.org/experts-assess-iran-agreement-20158507 [http://perma.cc/Y7TX-5PSV] (including commentary from Lawrence Korb and Katherine Blakely of the Center for American Progress, stating that the Iran nuclear deal "was one of the most comprehensive and detailed nuclear arms agreements ever reached.").

3. Eyder Peralta, 6 Things You Should Know About the Iran Nuclear Deal, NPR (July 14, 2015, 3:05 PM), available at http://www.npr.org/sections/thetwo-way/2015/07/14/422920192/6things-you-should-know-about-the-iran-nuclear-deal [http://perma.cc/8SF4-NSBG].

4. Country Profiles: Iran: Nuclear, Nuclear Threat Initiative, http://www.nti.org/country-profiles/iran/nuclear/ [http://perma.cc/2V97-G4DV] (last visited Oct. 2015).

5. Id. 
Iran's nuclear program was temporarily halted starting in 1979, when the Iranian Revolution took place, and much of Iran's nuclear talent fled the country in the wake of the Revolution. ${ }^{6}$ The nuclear program continued to be suspended after the Revolution, because the new Iranian leader, Ayatollah Ruhollah Khomeini, was initially opposed to nuclear technology, and because Iran was engaged in a costly war with Iraq from 1980 to 1988, which effectively disabled Iran from pursuing any type of nuclear technology. ${ }^{7}$

In the late 1980s, Iran revived its nuclear weapon program, with assistance from Pakistan, China, and Russia. Pakistan entered into a bilateral agreement with Iran in 1992, China in 1990, and Russia in 1992 and $1995 .{ }^{8}$ While Iran has always maintained that its nuclear work was peaceful and that any nuclear programs undertaken were for civilian purposes, ${ }^{9}$ United States' intelligence agencies suspected Iran of using the civilian nuclear program as a cover for clandestine nuclear weapons development. ${ }^{10}$

In August 2002, an Iranian dissident group publicly revealed the existence of two undeclared nuclear facilities, the Arak heavy-water production facility and the Natanz enrichment facility. ${ }^{11}$ Following this revelation, in February 2003, Iranian President Mohammad Khatami acknowledged the existence of these facilities but argued that Iran undertook "small-scale enrichment experiments" to produce low-enriched uranium for nuclear power plants. ${ }^{12}$ After the International Atomic Energy Agency (IAEA) inspectors visited Natanz, and other sites, they concluded, in a May 2003 report, that Iran violated the terms of previous nuclear agreements. ${ }^{13}$ In June 2003, Iran entered into diplomatic negotiations with France, Germany, and the United Kingdom; the United States, however, refused to participate. ${ }^{14}$ These negotiations resulted in the Tehran Declaration in October 2003.15 The Declaration, signed by France,

6. Id.

7. Id.

8. Id.

9. Iran Nuclear Talks: 'Historic' Agreement Struck, BBC News (July 14, 2015), http://www.bbc.com/news/world-middle-east-33518524 [http://perma.cc/5CLL-ZKXE].

10. See Country Profiles: Iran: Nuclear, supra note 4.

11. Kate Lyons, Iran Nuclear Talks: Timeline, GUARDIAN (July 14, 2015 3:45 AM), http://www.theguardian.com/world/2015/apr/02/irannuclear-talks-timeline [http://perma.cc/2FYB-H2QB].

12. Country Profiles: Iran: Nuclear, supra note 4.

13. Lyons, supra note 11.

14. Lyons, supra note 11.

15. Lyons, supra note 11. 
Germany, the United Kingdom, and Iran, provided that Iran would cooperate fully with the IAEA and temporarily suspend all uranium enrichment. ${ }^{16}$ The Tehran Declaration was followed by the Paris Agreement in November 2004, according to which Iran agreed to temporarily suspend both enrichment and conversion activities, including the manufacture and operation of centrifuges. ${ }^{17}$

The Paris Agreement fell apart after the election of hard-liner Mahmoud Ahmadinejad in August 2005. ${ }^{18}$ Iran notified the IAEA that it would resume uranium conversion and enrichment at several nuclear sites; prompting the IAEA Board of Governors to refer Iran to the Security Council. ${ }^{19}$ Between 2006 and 2010, the Security Council adopted six different resolutions concerning Iran's nuclear program; these resolutions demanded that Iran cease enrichment activities and imposed sanctions, including freezing the assets of certain Iranian individuals and companies. ${ }^{20}$

In September 2009, President Obama, revealed the existence of an underground enrichment facility in Fordow and argued that "Iran's decision to build yet another nuclear facility without notifying the IAEA represents a direct challenge to the basic compact at the center of the non-proliferation regime." ${ }^{21}$ The relationship between the United States and Iran remained stalled until March 2013, when the United States began a series of secret bilateral talks with Iranian officials in Oman. ${ }^{22}$ While public information about the nature of these talks has been largely unavailable, one can presume that the Obama Administration was hoping to establish more candid and forthcoming communication with Iranian leadership, paving the way for more formal nuclear disarmament negotiations after the Iranian

16. Lyons, supra note 11.

17. Country Profiles: Iran: Nuclear, supra note 4.

18. Stephen J. Hadley, Iran Primer: The George W. Bush Administration, PBS Frontline (Nov. 3, 2010, 1:05 PM), available at http://www.pbs.org/wgbh/pages/frontline/tehranbureau/2010/11/iranprimer-the-george-w-bush-administration.html [http://perma.cc/8BMLJHXM].

19. Id.; Country Profiles: Iran: Nuclear, supra note 4; Lyons, supra note 11.

20. Hadley, supra note 18.

21. Jesse Lee, "A Growing Concern that Iran is Refusing to Live Up to Those International Responsibilities," White House (Sept. 25, 2009, 11:39 AM), https://www.whitehouse.gov/blog/2009/09/25/a-growingconcern-iran-refusing-live-those-international-responsibilities [http://perma.cc/KQQ4-E2BV].

22. Laura Rozen, Three Days in March: New Details on How U.S., Iran Opened Direct Talks, BACK CHANNEL (Jan. 8, 2014), http://backchannel.al-monitor.com/index.php/2014/01/7484/threedays-in-march-new-details-on-the-u-s-iran-backchannel/ [http://perma.cc/RS3W-6RXT]. 
elections, which had been scheduled for June 2013. ${ }^{23}$ In June 2013, Hassan Rouhani, a more moderate and pragmatic politician, was elected president of Iran. ${ }^{24}$ In August 2013, three days after his inauguration, Rouhani called for a resumption of serious negotiations with the West on the Iranian nuclear program. ${ }^{25}$ In September 2013, Obama and Rouhani had a telephone conversation, the first high-level contact between the United States and Iranian leaders since 1979. ${ }^{26}$ Additionally, Secretary of State John Kerry met with Iranian foreign minister, Mohammad Javad Zarif, signaling that the two countries had begun to negotiate and perhaps cooperate. ${ }^{27}$

After several rounds of negotiations, an interim agreement on the Iranian nuclear program was signed on November 24, 2013, by the same actors that are currently parties to the Agreement: the United States, Russia, Great Britain, France, China, the European Union, and Iran. ${ }^{28}$ The interim agreement - the Joint Plan of Action-was signed in Geneva, Switzerland. ${ }^{29}$ It provided for a short-term suspension of portions of Iran's nuclear program in exchange for decreased economic sanctions, as the countries continued to work toward a long-term agreement. ${ }^{30}$ The IAEA also began "more intrusive and frequent inspections" under this Interim agreement. ${ }^{31}$ The interim agreement was formally implemented on January 20, $2014 .{ }^{32}$

23. Id. (noting that the talks "helped provide some basis [for understanding]...").

24. Lyons, supra note 11.

25. Timeline of Nuclear Diplomacy with Iran, Arms CONTROL Ass'N, available at https://www.armscontrol.org/factsheet/Timeline-of-NuclearDiplomacy-With-Iran [http://perma.cc/6BS2-MKMN] (last updated Oct. 2015).

26. $I d$.

27. $I d$.

28. Anne Gearan \& Joby Warrick, World Powers Reach Nuclear Deal with Iran to Freeze Its Nuclear Program, WASH. POST (November 24, 2013), available at https://www.washingtonpost.com/world/nationalsecurity/kerry-in-geneva-raising-hopes-for-historic-nuclear-deal-withiran/2013/11/23/53e7bfe6-5430-11e3-9fe0-fd2ca728e67c_story.html [http://perma.cc/8FLK-FA3E].

29. Id.

30. $I d$.

31. Timeline of Nuclear Diplomacy with Iran, supra note 25.

32. Timeline of Nuclear Diplomacy with Iran, supra note 25. See also Fredrik Dahl \& Justyna Pawlak, West, Iran Activate Landmark Nuclear Deal, REUTERS, (Jan. 20, 2014), available at http://www.reuters.com/article/2014/01/20/us-iran-nuclearidUSBREA0J00420140120 [http://perma.cc/7T5M-RLJ3]. 
After the interim agreement was activated, all relevant parties agreed to continue their talks, with the goal of reaching a long-term agreement over the subsequent months. ${ }^{33}$ The parties reached an initial deal framework on April 2, 2015 in Lausanne, Switzerland; under this framework, Iran tentatively agreed to accept restrictions on its nuclear program for at least a decade, and to submit to an increased international inspections regime. ${ }^{34}$ The last set of contentious negotiations took place over the course of seventeen days in Vienna, in late June and July 2015, resulting in the current Agreement, signed on July 14, 2015 and based on the April 2, 2015 framework. ${ }^{35}$

\section{Basics of the Agreement}

Under the terms of the Agreement, Iran agreed to limit its nuclear program in several ways. First, Iran agreed to decrease its stockpile of low-enriched uranium by 98 per cent; the Agreement contemplates that this reduction will remain in place for fifteen years. ${ }^{36}$ Moreover, during the same fifteen-year period, Iran will be limited to enriching uranium to $3.67 \%$, a percentage sufficient for civilian nuclear power and research, but not for building nuclear weapons. ${ }^{37}$ Second, Iran

33. Louis Charbonneau \& Fredrik Dahl, Iran Warned of 'Last Chance' in Nuclear Talks After Deadline Missed, REUTERS (July 19, 2014, 1:20AM), http://www.reuters.com/article/2014/07/19/us-iran-nuclearidUSKBNOFN27020140719 [http://perma.cc/HXD6-S7ML].

34. Lyons, supra note 11; Timeline of Nuclear Diplomacy with Iran, supra note 25; Eric Bradner, What's in the Iran Nuclear Deal? 7 Key Points, CNN Politics (Apr. 2, 2015, 6:56 PM), http://www.cnn.com/2015/04/02/politics/iran-nuclear-deal-main-pointsof-agreement/ [http://perma.cc/U6SZ-XTCU].

35. During the negotiations, it is reported that U.S. Secretary of State John Kerry directly asked Iranian Foreign Minister Mohammad Javad Zarif to confirm that he was "authorized to actually make a deal, not just by the [Iranian] president, but by the supreme leader?" Zarif gave assurances that he was. Karen DeYoung and Carol Morello, The Path to a Final Iran Nuclear Deal: Long Days and Short Tempers, WASH. POST (July 15, 2015), https://www.washingtonpost.com/world/national-security/long-daysand-short-tempers-the-path-to-a-final-nucleardeal/2015/07/15/bb90235c-2b1d-11e5-bd33-395c05608059_story.html [http://perma.cc/KDV5-9F8V]; Lyons, supra note 11.

36. Michael R. Gordon \& David E. Sanger, Deal Reached on Iran Nuclear Program; Limits on Fuel Would Lessen With Time, N.Y. TIMES (July 14, 2015), available at http://www.nytimes.com/2015/07/15/world/middleeast/iran-nucleardeal-is-reached-after-long-negotiations.html? $\_r=0$ [http://perma.cc/S2KM-9VQN].

37. Peralta, supra note 3. 
agreed to place over two-thirds of its centrifuges in storage and to limit any enrichment capacity to only the Natanz plant, which will be monitored by the IAEA. ${ }^{38}$ This limitation will remain in place for ten years. ${ }^{39}$ Third, Iran agreed to refrain from building any new uraniumenrichment facilities for fifteen years. ${ }^{40}$ Under the terms of the Agreement, Iran may continue research and development work on enrichment, but that work will be restricted to the Natanz facility and will be subject to enumerated limitations for the first eight years. ${ }^{41}$ Fourth, Iran agreed to cease enriching uranium at the Fordow facility for at least fifteen years; instead, the Fordow facility will be converted into a nuclear physics and technology center. Fordow, an underground facility, had been at the center of international anxiety because many believed that Iran was enriching uranium in centrifuges at this facility. ${ }^{42}$ Fifth, Iran will implement an Additional Protocol agreement, which will continue in perpetuity for as long as Iran remains a party to the NPT. Iran's acceptance of the Additional Protocol is particularly important, because it represents a continuation of the monitoring and verification provisions after the entire nuclear Agreement is implemented. ${ }^{43}$ Sixth, Iran agreed to a comprehensive inspection and verification regime by the IAEA. The IAEA will have continuous monitoring access to Iran's declared nuclear sites, such as Natanz and Fordow. ${ }^{44}$ The IAEA inspection team will consist of 150 inspectors, which prior to the Agreement, the inspection team had comprised of only 50 inspectors. The Agreement also authorizes the IAEA to use various types of sophisticated monitoring technology, such as fiber-optic seals on equipment that can electronically send information to the IAEA, infrared satellite imagery to detect covert sites, environmental sensors that can detect minute signs of nuclear particles, tamper-resistant, radiation-resistant cameras, as well as computerized accounting programs to gather information and detect anomalies, and big data sets on Iranian imports, to monitor dual-use items. ${ }^{45}$ In addition to monitoring

38. Gordon \& Sanger, supra note 36; Joint Comprehensive Plan of Action, supra note 1.

39. See sources cited supra note 38 .

40. Bradner, supra note 34 .

41. Peralta, supra note 3.

42. Peralta, supra note 3 .

43. Factsheet: Iran and the Additional Protocol, CTR. ARMS CONTROL \& Non-Proliferation (July 14, 2015), available at http://armscontrolcenter.org/factsheet-iran-and-the-additional-protocol/ [perma.cc/7E3X-TD7F].

44. Peralta, supra note 3 . 
declared nuclear sites, IAEA inspectors will also be able to request access to non-declared nuclear facilities. ${ }^{46}$

Experts estimate that under these restrictions Iran's "break-out" time - the time needed to build a nuclear weapon -will increase from two to three months to an entire year. ${ }^{47}$ The estimated one year break-out time would remain in place for ten years, but could significantly decrease by the Agreement's expiration date in fifteen years. ${ }^{48}$ Finally, the Agreement provides a dispute resolution procedure for when a party to the Agreement suspects that Iran is not complying with the terms of the Agreement. Ultimately, "[t]he deal lays out a scheme in which if there is a dispute about Iran meeting its obligations, the full U.N. Security Council would 'vote on a resolution to continue the sanctions lifting.'" 49 This is what the Obama Administration refers to as "snap-back" sanctions. ${ }^{50}$

In exchange for its compliance with the Agreement, Iran will benefit from suspension and termination of various economic and nuclear sanctions. First, the Agreement contemplates that no new United Nations or European Union nuclear-related sanctions or

45. Tim Mak, The Spy Tech That Will Keep Iran in Line, DAILY BEAST (July 6, 2015, 1:03 AM), http://www.thedailybeast.com/articles/2015/07/06/the-spy-tech-thatwill-keep-iran-in-line.html [perma.cc/XEF5-DVZ9].

46. Rebecca Kaplan, Obama says inspectors get access to "any" site in Iran. Is it true?, CBS NEWS (July 14, 2015, 10:40 PM), http://www.cbsnews.com/news/obama-inspectors-access-any-site-irantrue/ [perma.cc/HFR9-QDXJ].

47. Gordon \& Sanger, supra note 36, Bradner, supra note 34.

48. See sources cited supra note 47.

49. Peralta, supra note 3.

50. For a detailed account of "snap-back" sanctions under the Agreement, see Ankit Panda, How the Iran Deal's 'Snap Back' Mechanism Will Keep Tehran Compliant, DIPLOMAT (July 15, 2015), http://thediplomat.com/2015/07/how-the-iran-deals-snap-backmechanism-will-keep-tehran-compliant/ [perma.cc/7HJZ-NYXP]("if any of the signatories of the JCPOA have any reason to believe that another party is not upholding its commitments under the agreement....they can refer the issue to a Joint Commission for resolution. If a non-Iran party raises an issue with the commission and isn't too happy with the result.....it can notify the UN Security Council. The Security Council has 30 days to make a move, i.e. adopt a resolution on the specific issue at hand. Where the United States preserved unique leverage-and immunity from a Russian or Chinese veto against resuming old UN Security Council sanctions-is the next step. If the Security Council doesn't act in 30 days, all of the pre-JCPOA nuclear-related sanctions on Iran come back into place automatically. Basically, the U.S. and the EU states in the $\mathrm{P} 5+1$ can veto ongoing sanctions relief but Russia and China can't veto a return to the status quo ante."). 
restrictive measures will be imposed ${ }^{51}$ After the IAEA issues a report verifying Iran's implementation of the nuclear-related measures, the United Nations' sanctions against Iran will terminate, and some European Union sanctions will terminate or be suspended. ${ }^{52}$ Moreover, the United States promised to stop imposing nuclear-related sanctions against Iran at some point in the first half of $2016 .{ }^{53}$ Most importantly for Iran, once these various sanctions are lifted, Iran will be positioned to recover approximately $\$ 100$ billion of its assets frozen in overseas banks. ${ }^{54}$ Sanctions for ballistic missile technologies will remain in place for another eight years, and similar sanctions on conventional weapon sales will remain for five years. ${ }^{55}$ However, all other United States sanctions against Iran relating to human rights abuses, missiles, and support for terrorism will not be affected by the Agreement, and will likely remain in place. ${ }^{56}$ These sanctions are deemed to be more stringent because many have so-called extra-territorial effect and apply worldwide.

\section{IV. (Dis)Advantages of the Agreement}

The most important advantages of the Iran Nuclear Agreement, if successfully implemented, are that Iran's break-out time will be augmented to one year, and that Iran will be subject to various inspections and verification programs by the international community over the next fifteen years. ${ }^{57}$ While some argue that the Agreement only postpones Iran's ability to manufacture a nuclear weapon by fifteen years, others emphasize that this result is nonetheless more advantageous than the pre-Agreement situation, where Iran may have

51. Jessica Simeone \& Anup Kaphle, Here Are The Highlights Of The Iran Nuclear Agreement, BUZZFEEDNEWS (July 14, 2015, 8:56 AM), http://www.buzzfeed.com/jessicasimeone/here-are-the-highlights-of-theiran-nuclear-agreement\#.tnWp81VQ1 [perma.cc/YW2V-CGQM].

52. Explainer: The Iran nuclear deal, European Council Foreign REL. (July 17, 2015), available at http://www.ecfr.eu/article/iran_explainer3070 [perma.cc/SRF5-NCUH].

53. $I d$.

54. Jackie Northam, Lifting Sanctions Will Release $\$ 100$ Billion To Iran. Then What?, NPR (July 16, 2015, 3:53 PM) available at http://www.npr.org/sections/parallels/2015/07/16/423562391/liftingsanctions-will-release-100-billion-to-iran-then-what [perma.cc/MCT7$\mathrm{J} 4 \mathrm{PY}]$.

55. Gordon \& Sanger, supra note 36.

56. Felicia Schwartz, When Sanctions Lift, Iranian Commander Will Benefit, WALL ST. J. (July 15, 2015), http://blogs.wsj.com/washwire/2015/07/15/when-sanctions-lift-iraniancommander-will-benefit/ [perma.cc/49P9-3PMZ].

57. See supra Part III. 
been just months shy of having a nuclear arm. Moreover, it is entirely plausible that Iran will cease the production of nuclear weapons altogether and indefinitely, in light of ongoing inspections and verifications imposed by the Agreement, and encouraged by the lifting of various international sanctions as a result of compliance. In addition, many in the international community believe that the most important feature of the Iran Nuclear Agreement is that Iran will, once again, become re-engaged in the international arena. Because the Agreement provides for the lifting of various economic sanctions that crippled Iran's economy for decades, Iran has every incentive to comply with the terms of the Agreement and to attempt to rebuild not just its economy, but also a reputation as a non-rogue world player. Reports hail the deal, writing that "One of the most important implications of the comprehensive nuclear agreement between Tehran and the great powers is the renewed faith in the power of diplomacy." 58

The clearest disadvantage of the Agreement is its limited duration. As discussed above, most inspections and limitations on Iran's nuclear program will cease after the first fifteen years, and most experts concede that Iran's break-out time will return to its current two-three month frame. ${ }^{59}$ Additionally, the Agreement contains several provisions that the United States and its allies may view as concessions or mini "victories" for Iran. For example, the Agreement allows Iran to continue enriching uranium for non-military purposes. ${ }^{60}$ This provision can be interpreted as giving Iran approval to maintain a small-scale nuclear program. Critics of the deal have pointed out that the Agreement does not dismantle Iran's nuclear program altogether, and that Iran could, in fifteen years, resume operating a larger military-purpose oriented nuclear production. ${ }^{61}$ Moreover, under the terms of the Agreement, IAEA inspectors will have continuous access to declared nuclear sites, but will have to ask Iran's permission to visit any non-declared sites. Iran will not be required to grant access for several weeks, which may enable it to hide and remove any forbidden nuclear production items. ${ }^{62}$ Finally, critics of the deal have

58. Richard Javad Heydarian, Iran nuclear deal is a triumph of diplomacy, AljazeERA (Aug. 8, 2015, 8:07 GMT), http://www.aljazeera.com/indepth/opinion/2015/07/iran-nuclear-dealtriumph-diplomacy-150726121334719.html [perma.cc/B3TB-KQXV].

59. For a detailed discussion of the Agreement's duration, see supra Part III.

60. See, e.g., Peralta, supra note 3.

61. See Peralta, supra note 3 (even President Obama has conceded that, at the expiration of the Agreement in 15 years, Iran's break-out time could return to zero).

62. See supra Part III. 
emphasized that snap-back sanctions, which would be re-imposed on Iran if it violates the terms of the Agreement, are not automatic ${ }^{63}$ In fact, under the terms of the Agreement, a party to the Agreement may refer a potential violation thereof to the Security Council, which will have thirty days to adopt a resolution to continue the lifting of sanctions. If such a resolution is not adopted within thirty days, then pre-Agreement nuclear sanctions would automatically be re-imposed ${ }^{64}$ The effect of this rule is that any permanent member of the Security Council (the U.S., Britain, China, Russia and France) can veto any ongoing sanctions relief, but no member can veto the re-imposition of sanctions. ${ }^{65}$ Moreover, Iran has stated that in such a case, it would cease performing its nuclear obligations under the Agreement. Critics of the Agreement have argued that because the Agreement provides that Iran could treat reinstatement of sanctions (in part or entirely) as grounds for leaving the agreement, the United States and other parties to the Agreement will be reluctant to impose "snap-back" sanctions for smaller violations. One critic remarked, "the only thing you'll take to the Security Council are massive Iranian violations, because you're certainly not going to risk the Iranians walking away from the deal and engaging in nuclear escalation over smaller violations." $" 66$

The International Community has widely accepted the Agreement with all its relative advantages and disadvantages ${ }^{67}$ In the United States, however, it remains to be seen whether President Obama will be able to persuade the American Congress and public on the merits of this now infamous Agreement.

\section{Post-Agreement: Implementation and Obama's LEGACY?}

The Security Council and the European Union approved the Agreement; moreover, President Obama signed the Agreement as an

63. See Karoun Demirjian, Twelve things in the Iran deal that lawmakers can't agree on, WASH. POST (July 23, 2015), http://www.washingtonpost.com/graphics/world/issues-with-iran-deal/ [perma.cc/485R-H2SQ] (providing a detailed discussion of disagreements between those who support and oppose the Agreement).

64. See Joint Comprehensive Plan of Action, supra note 1 at 936 .

65. See Panda, supra note 50.

66. Michele Kelemen, A Look At How Sanctions Would 'Snap Back' If Iran Violates Nuke Deal, NPR (July 20, 2015, 5:16 AM), available at http://www.npr.org/2015/07/20/424571368/if-iran-violates-nuke-deal-alook-at-how-sanctions-would-snap-back [perma.cc/BDG8-6YF6] (quoting Mark Dubowitz, sanctions expert at the Foundation for Defense of Democracies, which has been campaigning against the Agreement).

67. See infra Part V. 
Executive Act. ${ }^{68}$ However, under a recently passed federal statute, socalled Nuclear Agreement Review Act of $2015,{ }^{69}$ Congress may pass a resolution approving or disapproving the Agreement within sixtydays. ${ }^{70}$ If the United States Congress disapproves the Agreement,

68. Somini Sengupta, U.N. Moves to Lift Iran Sanctions After Nuclear Deal, Setting Up a Clash in Congress, N. Y. TIMES (July 20, 2015), http://www.nytimes.com/2015/07/21/world/middleeast/securitycouncil-following-iran-nuclear-pact-votes-to-lift-sanctions.html? $\_r=0$ [perma.cc/8L6F-SJEW] (reporting that the Security Council voted 15-0 to adopt a resolution approving the Agreement, and that on the same day, the European Union also confirmed the Agreement); Amber Phillips, Can Congress stop the Iran deal?, WASH. POST (July 14, 2015), http://www.washingtonpost.com/news/the-

fix/wp/2015/07/09/the-role-of-congress-or-lack-thereof-in-the-iran-dealexplained/ [perma.cc/SA4G-MKFA] (noting that the Agreement is an executive act and discussing the difference between formal treaties, requiring a two-thirds congressional approval, and executive agreements which the president can sign on his or her own). In United States' constitutional history, there is ample precedent for the legality of signing agreements in the form of executive acts or agreements. In 2003, the U.S. Supreme Court held in American Insurance Association v. Garamendi that "our cases have recognized that the President has authority to make 'executive agreements' with other countries, requiring no ratification by the Senate or approval by Congress, this power having been exercised since the early years of the Republic. See American Insurance Association v. Garamendi, 539 U.S. 396 (2003). Although some criticized the form of the Agreement, arguing that it should be considered a treaty rather than an executive agreement, other prominent commentators disagree. See Lee A. Casey, The Lawless Underpinnings of the Iran Nuclear Deal, WALL ST. J., July 27, 2015, A13 (arguing that the Agreement should have been considered a treaty requiring two-thirds approval by both houses of congress). But see Jack Goldsmith, More Weak Arguments For The Illegality of the Iran Deal, LAWFARE BLOG (July 27, 2015), https://www.lawfareblog.com/moreweak-arguments-illegality-iran-deal [https://perma.cc/R9VR-RXEE] (calling arguments for the illegality of the agreement "weak"); John Yoo, Why Obama's Executive Action on Iran Does Not Violate the Law, NAT'L REV. (July 26, 2015), http://www.nationalreview.com/article/421621/iran-deal-constitionsupports-obama-executive-action [https://perma.cc/P2XT-BNVZ] (arguing that the executive agreement form of the Agreement is consistent with the Treaty Clause of the Constitution).

69. The Iran Nuclear Agreement Review Act of 2015, Pub. L. No. 114-17. $\S 2,129$ Stat. 201 (42 $\S 2160$ e) (legislative history shows the act was an amendment to the Atomic Energy Act of 1954 and passed by the Senate as S. 615 on May 7, 2015, in a 98-1 vote. It was passed by the House as H.R. 1191 on May 14, 2015, in a 400-25 vote, and it was approved by President Obama on May 22, 2015.).

70. See Phillips, supra note 68 (noting that the Nuclear Agreement Review Act was passed as a compromise between President Obama and Congress, and that the Act gives Congress the ability to review any agreement signed with Iran). 
President Obama will most certainly veto Congressional disapproval. Congress will need a vote by two-thirds of both houses of Congress to override President Obama's veto. ${ }^{71}$ Because it is extremely unlikely that Congress will be able to override the presidential veto, it is highly probable that the Agreement will become part of American law. As such, this Agreement may constitute the hallmark of President Obama's diplomatic efforts and achievements.

In urging Congress to approve the Agreement, President Obama stated; "If we don't choose wisely, I believe future generations will judge us harshly, for letting this moment slip away." 72 The legacy of the Obama presidency may lie in this diplomatic achievement-Iran's re-engagement in the international arena and the end of worldwide speculations that the Iranian rogue regime was secretly building a nuclear weapon. President Obama himself has argued that the success of this Agreement should not be assessed by whether the Iranian regime is ultimately transformed, but by the more modest goal of the Agreement, which was to stop Iran from acquiring a nuclear weapon. However, it may be that the Obama legacy, in terms of foreign relations with Iran, will depend on this Agreement's ability to steer Iran toward a more democratic form of governance. ${ }^{73}$ As Thomas Friedman recently opined, "I suspect [President Obama's] legacy on this issue will ultimately be determined by whether the deal does, in the long run, help transform Iran, defuse the U.S.-Iran Cold War and curtail the spread of nuclear weapons in the Middle East - not foster their proliferation." Only time will tell whether President Obama was correct in steering the nation toward the Agreement. His legacy will, in many ways, depend on the shrewdness of this particular political calculus.

\section{CONCLUSION}

In defending the Agreement, President Obama argued "this deal will make America and the world safer and more secure." ${ }^{74}$ The

71. Phillips, supra note 68.

72. Gardiner Harris \& Michael D. Shear, Obama Begins 60-Day Campaign to Win Over Iran Deal Skeptics at Home and Abroad, N. Y. TIMES (July 15, 2015), http://www.nytimes.com/2015/07/16/world/middleeast/iran-nucleardeal-approval-urged-by-obama.html [https://perma.cc/F3GM-SM7R].

73. Thomas L. Friedman, Obama Makes His Case on Iran Nuclear Deal, N. Y. TIMES (July 14, 2015), http://www.nytimes.com/2015/07/15/opinion/thomas-friedman-obamamakes-his-case-on-iran-nuclear-deal.html [perma.cc/8FER-D9YS].

74. Office Press Sec'y, WEEKLY ADDRESS: A Comprehensive, Long-Term Deal with Iran (July 18, 2015) (transcript available at https://www.whitehouse.gov/the-press-office/2015/07/18/weeklyaddress-comprehensive-long-term-deal-iran [perma.cc/SZL8-T4HB]). 
Agreement, which curbs Iran's ability to develop nuclear weapons over the next fifteen years, may lead to global safety, peace in the Middle East, and nuclear non-proliferation. If this proves to be true, the Agreement would constitute President Obama's most significant foreign policy achievement and would be viewed as a cornerstone of his legacy. 